\title{
IAMJ
}

INTERNATIONAL

AYURVEDIC

MEDICAL JOURNAL

ISSN: 2320-5091

Impact Factor: 6.719

\section{ENVISIONING OF RASASHASTRA IN PRESENT PANDEMIC}

\author{
Vidhiya Malviya1, Pramod Patel ${ }^{2}$, Anil Nagle ${ }^{3}$ \\ ${ }^{1}$ PG Scholar, ${ }^{2} \mathrm{MD}$ (Ayu) Lecturer, ${ }^{3} \mathrm{MD}$ (Ayu) Professor \& HOD \\ Dept. of RSBK, Pt. Khushilal Sharma Govt. Ayurveda College \& Institute, Bhopal, Madhya Pradesh, India
}

Corresponding Author: vidhiya.malviya@gmail.com

https://doi.org/10.46607/iamj.3209012021

(Published online: January 2021)

Open Access

(C) International Ayurvedic Medical Journal, India 2021

Article Received: 25/12/2020 - Peer Reviewed: 02/01/2021 - Accepted for Publication: 06/01/2021

Check for updates

\begin{abstract}
Rasashastra- A pharmaceutical science has following characteristic attributes i.e. instant effectiveness, requirement of very small doses and extensive therapeutic utility irrespective of statutory variation. Aims - To know the variety of formulation for SARS CoV-2 and also know the kind of disinfectant or sanitizer of Rasa medicine. Material and Method - Rasa medicine with its huge importance on treating chronic diseases also beneficiary in making disinfectant. Critical review of Rasashastra treatises give some beneficiary formulation that can be used in this pandemic. Result - List of herbo-mineral formulation from different Rasashastra treatises are compiled. This formulation plays very important role in treating communicable disease from stopping the spread of virus to treat the disease and also symptomatic treatment with particular medicine. Conclusion - In present time a big threat for human civilization is come in the form of corona epidemic and become pandemic. This is one of the challenges towards whole world that how to combat with the situation. Presently when no one knows the treatment, Ayurveda plays a very important role with its huge Ayurvedic formulations and unique strategy of treatment protocol. A Pharmaceutical science "Rasashastra" plays a very indispensable role because of wide range of Ayurvedic formulations described in Rasashastra treatises along with wide therapeutic utility.
\end{abstract}

Keywords: Herbo-mineral formulation, Disinfectants

\section{INTRODUCTION}

Rasashastra - a vast pharmaceutical science and a specialized branch of Ayurveda dealing mainly with materials which are known as 'Rasa Dravyas'. This Rasa Dravays are metal, mineral \& herbo-mineral 
drugs. The literally mean of Rasashastra is "Science of mercury". This pharmaceutical science has following characteristic attributes i.e. instant effectiveness, requirement of very small doses and extensive therapeutic utility irrespective of constitutional variation. The following Shloka describes the above given attributes of Rasa. ${ }^{1}$ अल्पमात्राउपयोगित्वातअरुचेअप्रसगात क्षिप्रम्आरोग्यम्दायित्वात्औषधेक्योऽधिकोरस:|| (R.R.S. 28/1)

In present time a big threat for human civilization is come in the form of corona epidemic and become pandemic. This is one of the challenges towards whole world that how to combat with the situation. Presently when no one knows the treatment, Ayurveda plays a very important role with its huge Ayurvedic formulations and unique strategy of treatment protocol. A Pharmaceutical science "Rasashastra" plays a very indispensable role because of wide range of Ayurvedic formulations described in Rasashastra treatises along with wide therapeutic utility.

\section{EPIDEMIOLOGY IN AYURVEDA :2}

Epidemiology in Ayurveda known to be as Janpadoudhvans and its main cause according to Ayurveda is Adharma (Iniquity). This adharma happen as a result of doing pragyapradh (The things which are not willing to be good). This pragyapradh manifest in the human civilization by disturbing the environmental factors in the form of communicable disease. Epidemiology: Epi - Among, Demos - people, and Logos Study, Epidemiology is the study of distribution and determination of health-related states or events in specified population and the application of this study to control of health problems.

Throughout the course of history, disease outbreaks have ravaged humanity. Here are the list of worst epidemics and pandemics, dating from prehistoric to modern times.

Circa 3000 B.C., The Black Death: 1346-1353, Cocoliztli epidemic: 1545-1548, American Plagues: 16th century, Great Plague of London: 1665-1666, Philadelphia yellow fever epidemic: 1793, Flu pandemic: 1889-1890, American polio epidemic: 1916, Spanish Flu: 1918-1920, Asian Flu: 1957-1958, AIDS pandemic: 1981-present day, H1N1 Swine Flu pandemic:
2009-2010, West African Ebola epidemic: 2014-2016, Covid - $19: 2020$

Novel corona virus was first reported in Wuhan, Hubei province, China, in December 2019 and have since spread across the world. Presently worldwide $7,90,30,826$ cases found till today. In India $1,01,23,778$ confirmed cases found and in Madhya Paradesh 2,34,000 cases found.

\section{Etiology of Epidemic}

According to Ayurveda etiological factors are divided In Ahara, Vihar and Vichar of individual. Many unappropriated things that individual performs in their daily routine become a cause of disease. For eg. unhealthy diet, uneven time of eating, improper siting, eating junk food-meats of animal, not follow healthy life style, not doing proper work at right time, uneven time of wake up and sleep, importantly disturb the geographic area by building company and society and cutting the plants, use of chemicals in various dietary products and disturbing environmental air by pollution etc.

Rasashastra mainly focus on Ayurvedic formulation but not give much emphasis on disease pathology or etiology. The actual condition of epidemiology is briefly described in Charaka Samhita one of the oldest $\&$ renowned Grantha of Ayurveda. तदात्वेचानुबंधेवायस्यस्यादशुभंफलम ! कर्मणस्तन्नकर्तव्यमेतद्नुद्धिमतांमतम् !! (च.वि. 3/46). Acharya Charak in Janpadoudhvans (Epidemiology) says that the work on doing and in future provide a bed effect is very dangerous so never perform the action whose results are not good.

In Charaka Samhita acharya Punarvasu says about the Janpadoudhvans by answering the question of his student Agnivesh. Acharya says that although individual defer in physical constitution, age, place, food habits, immunity, adoptability, strength etc. and they do get affected with disease due to vitiation of some factors that are common to all individuals who settler in that community. These factors lead to the cumulatively manifestation of disease having the common set of symptoms among all the settler and leading to widespread of disease in community. Factors which are common in all individuals are Desh, Jala, Vayu, and Kala. Human as a host and disease-causing agent or 
Krimi inter-relate in a variety of complex ways to produce disease in humans. Their balance and interactions are different for different diseases.

\section{Rasashastra Tenets:}

All sciences are based on some of their own basic principles \& each one of them has its own definitions \& terminologies, which have meanings wider than what they seem to be. The development of Rasashastra has made from metals and minerals that pass through various processes like Shodhan, Marana, Jarana, etc. with the help of supporting processes like heating, boiling, grinding, triturating, etc. so as to convert these inorganic crude drugs or metals or minerals into a form or compound. These are some basic principle of Rasashastra. Rasashastra medicine work in human body on the principle of Alpamatraupyogitvat that is come in existence when the nano particle size of Bhasmas are evaluate. By virtue of this it is scientifically proven that the medicine of Rasadravyas in Alpamatra giving the great result. which may suit the human body and can be absorbed and assimilated easily into the system without causing any toxic symptoms. In most of the Dravyas, we know the basis for the use of a particular form and procedure. We also know the effects of a particular process.

\section{Treatment Protocol in Ayurveda:}

"The soil is more important than the seed" This concept underlies several Ayurveda treatment strategies. Ayurveda's principle therapeutic aim is to harmoniously restore the balance of mankind. Rasashastra is foremost science of Ayurveda \& came into light after $8^{\text {th }}$ century. A therapeutic purpose of Rasa medicine and wide range effect with minimal dose are described in Rasagranthas but due to lack of knowledge and fear of using toxic element in formulation. Rasa Chikitsa presently not as much implemented in practice. Rasashastra - a pharmaceutical science, where Rasashastri acharyas in his treatises Rasa Hridaya Tantra, Rasendrachintamani, Rasatarangini, and Anandkand also describe the Chikitsa pattern which can also be applied in epidemic condition. By Kshetrikaran procedure which encompasses with Panchan, Snehan, Swedan, Vaman, Virechan \& one of Krimipatan that work with cleaning the body \& apply
Rasayan therapy. Ayurveda mainly emphasized on community health by keeping environment clean and follows the swasthvrita by obey the deontology with daily healthy regime. Acharya Charaka describe the Samanyachikitsa of Janpadoudhvans i.e. "कर्मपंचविधंतेषाभैषजंपरमउच्यते...." (च.वि. 3/13). He says that apply the proper Panchkarma procedure by knowing the disease and its Prakrati. After that use the proper Rasayan therapy and follow sadavrita. Acharya Susruta stands no exception to this view. Acharya describe the Nidana Parivarjan as of first Chikitsa. Susruta also stand with his principal of shatkriyakal in which disease formation describe from its origin to become recover and provide the different phase of disease where Chikitsa can be applied. One more way of treatment is Prativish Chikitsa which is presently applied in the form of plasma therapy. The antibodies of disease person after treatment removes and give it to another ill person that work as Prativish in another person.

HOW TO MAINTAIN HYGINE AND BECOME DISINFECTANT

In the section of philosophy in Ayurved Samhita, Jain darshan said about the preventive measures where they described and follow some rules that are the needs of present time i.e. Mukhpatti (Mask), Ahinsakahar (Vegetarian food), Sangheta (Social distancing), Aalgav (Quarantine), Samyakekanta (Isolation) Along with this one most important thing is to maintain disinfect yourself by using disinfectant. And it can only be possible to become disinfect by entering in pharmaceutical science. Presently a big market of allopathy run in the way disinfectant as a form of sanitizer. In Ayurveda science when we talk about sanitizer some of herbal medicine and minerals are presently used to make sanitizer. They are effective but their shelf life is short so we can't use it for a long period. When we look into Rasashastra treatises some of the Rasa Aushadhies can be used as disinfectant Like Rasakarpura mentioned in Rasatarangini. It can be used as sanitizer for a long period.

Rasakarpura is the combination of Parad, Gandhakamla, and Saindhavlavana. It is one of the Kupipakwa Rasayan and prepared in Balukayantra by 
continuously giving Agni upto 4 Prahara (12 hrs). Rasakarpura sustain its shelf life by adding Nimbukamla in it and preserve it in Chakrika form. This Chakrika wt. about six Ratti called Bhutaghnachakrika store in glass bottle and then it can be useful for a long period. Bhutaghnachakrika with 1200 $\mathrm{ml}$ water form Rasakarpuradrava. This drava used as disinfectant. $^{3}$

संक्रामकगदोत्थानभूतघ्नस्तुविशेषतः।रसजैस्तुसमाख्यातोरसकर्पूरजोद्रवः॥

(R.T.

6/102)

Rasakarpurdrava kill the Sankramak microbe and used for cleaning the infected wound, wash the hand, leg, anus, genitalia.

Rasakarpura with different proportion of water:

1:1000 - Used to clean the syphilis wound \& other kinds of wound.

1:2000 - Shalya tantra vaidya used it to clean long chronic wound.

1:1000 - used to wash hand, leg and household things. 1:5000 - used to wash eyes, vagina, uterus and other sophisticated part.

List of Some Rasa Aushadhi in Present Pandemic: Acc. to Yogratnakar: ${ }^{4}$ Bhagottarvati, Rasaratnapradeepatparpati rasa, Yogratnavalitparadadi rasa, Kasashwasavidhunano rasa, Tamraparpati rasa, Nagvallabh rasa, Hemagarbhpottali rasa, Kaphakunja rasa, Unmattbhairav rasa, Shwasakuthar rasa Acc. To Rasatantra Sara Evum Sidhhprayog Sangrah: ${ }^{5}$

In Shwasaroga with different pathological condition : Shwasaroga with anxiety \& weakness - Abrakabhasma, Shwasakasachintamani, Brahutsuwarnamalinibasant, Vanshagatshwasa - Shwasakasachintamani, Brahutsuwarnamalinibasant, Shwasakruchhta - Chaturbhuj rasa, Shwasakasa Chintamani, In shwasanalikaprasarana (Dilation of bronchioles) - Rasaraj rasa, Rasayanbindu, Shwasarogi addicted with nicotin (Tambaku) - Kasantakchurna, Shwasakasachintamani, For kaphastravarth - Kaphakunjar rasa, Pitta mrugank, Shwasakasa Chintamani, In senility - Brahutswarnamalini, Shwasakasa Chintamani, Hardik (Cardiac) shwasa - Lohabhasma, Abrakabhasma, Shwasakasachintamani, Shwasahari rasa, Kaphakunjar Rasa, Pratishyaysahshwasa - Naga rasayan,
Kaphakunjar rasa, Tamakshwasa - Jwarasahjwarariabhra, Pitta shwasakuthar, Raseshwararka, After attack of Tamakshwasa - Nagvallabh Rasa, Shwasahari rasa, if it is vataj-pittaj then use Swaranabhasma, Shwasakantak in kaphadhikya, Lohabhasma or Shwasakasachintamani in pitta prakop, In kaphadhikya Tamakshwasa - Amritarnav rasa, Shwasarilavana, Kaphaketu rasa, Mall shankhbhasma, Manahshilabhasma, Panchamritabhasma, Mall pushpa, Swachchhandbhairav, Nagavallabh, Naga rasayan, Samsharkarchurna.

Rasayoga that can be use in present pandemic condition and increase immune power:

- Recuperate from disease - Swarnamakshik Bhasma, Abhrak Bhasma, BrahutSuwarna Malini Basant,

- Pyrexia condition - Mrityunjaya Rasa, Tribhuvankirti Rasa, Jaymangal Rasa, Pratap Lankeshwar Rasa

- Safeguard of bronchi, bronchial and alveolar space - ShwasaKasa Chintamani Rasa

- Break the Dosha-Dushya Samurchhna - Sameerpannag Rasa, Rasasindoor with appropriate Anupan.

\section{DISCUSSION}

Ayurveda mainly emphasized on preserving the health and treat the disease is always secondary. The time has come to reanalyze the system of health management and look back at the Ayurveda philosophy of prevention and preservation as the first step to the treatment. But present time it is needed to reanalyze the knowledge of Rasashastra where treatment aspect is clear with various rasa medicine with minimal dose and high efficacy. Science if used wisely serves as a boon to humanity and if used in a wrong way can be dangerous. Same concept is also implemented on $R a$ sa Aushadhies. Because of minimal dose and great therapeutic efficacy in short duration treatment, Rasa aushadhies are treasure in human hand.

The indications, dose, vehicle, period of drug administration, interval or duration of treatment, disease diagnosed, nature or Prakruti of patient, PathyaApathya etc. are major factors which should always be 
considered by the physician before they recommend these Rasaushadhadravya's to the patients. The flaws and precautions related to the rational use of $R a$ saushadhi in Ayurveda are mentioned in classics. Here is an effort made to understand and highlight the concept of Rasaushadhi in Ayurveda. This aspect has been considered by the pioneers of Ayurveda in detail in addition to the other possible ways by which toxicity, untoward effects can occur and provided all the guidelines to avoid the occurrence of such incidences in Rasachikitsa .Presently the whole world facing an unprecedented pandemic of novel corona virus disease (COVID-19) caused by Severe Acute Respiratory Syndrome Corona virus 2 (SARS-CoV- 2). The disease has spread globally with more than 7,90,30,826 crore confirmed cases and 17,38,168 deaths as of December $24,2020 .^{6}$

\section{CONCLUSION}

The facet of pandemic requires an urgent harnessing of all medical science available globally. Every system has some flaws, which needs to be noted and rectified no matter how good the system is. Ayurveda is one of the ancient systems of medical science which has elaborated the causes and methods of druginduced consequences along with preventive measures.

\section{REFERENCES}

1. Kulkarni DA. Sutra Sthana 28/1. Rasa Ratna Samuchya of Acharya Vagbhatta. Delhi: Meharchand Lachhamandas publication;2010.

2. Dr. Tripathi Brhimanand. Charakviman - 3. Charak Samhita. Choukhambasurbhartiprakashan; 2010

3. Shastri KN. Chapter 6/102. Rasa Tarangini of shri Sadananda Sharma. 11th edi. Delhi: Motilal Banarsidas;2014.

4. Shastri Vaidhshreelakshmipati. Purvardh Kasa \& Shwasachikitsa, Yogratnakar, Choukhambaprakashan; 2017

5. Prof. Kaleda Krishnagopal, Pratham Khand, Rasatantrasara v Siddhprayog Sangraha, 2014 edition, Ajmer Rajasthan

6. www.worldometers.info

\section{Source of Support: Nil Conflict of Interest: None Declared}

How to cite this URL: Vidhiya Malviya et al: Envisioning of Rasashastra In Present Pandemic. International Ayurvedic Medical Journal \{online\} 2021 \{cited January, 2021\} Available from: http://www.iamj.in/posts/images/upload/200_204.pdf 